Kaygl, 20(I)/2021: 70-91. Araştırma Makalesi | Research Article

Makale Geliş | Received: 07.12.2020

Makale Kabul | Accepted: 29.01.2021

Yayın Tarihi | Publication Date: 15.03.2021

DOI: $10.20981 /$ kaygi.886090

\title{
Funda GENÇOĞLU
}

Prof. Dr.| Prof. Dr.

Atılım Üniversitesi, İşletme Fakültesi, Siyaset Bilimi ve Kamu Yönetimi Bölümü, Ankara, TR Atilim Univ., Fac. of School of Business, Dep. of Political Science and Public Administration, Ankara, TR

ORCID: 0000-0001-8211-8624

funda.gencogluonbasi@atilim.edu.tr

\section{Posthumanizm Tartışmasının Düșündürdükleri: Haddini Bilmek ile Haddini Așmak Arasında İnsan}

Öz

$\mathrm{Bu}$ makale posthümanizm tartışmalarının ancak kadim 'insan nedir' sorusunun geçmişten bugüne doğurmuş olduğu epistemolojik-etik-politik tartışmalarla birlikte ele alındığında bir açılım sağlayabileceğini iddia etmekte ve bunu gösterebilmek için, siyasal düşünceler tarihinde insanın düşünülüş biçimlerine dair orijinal bir kategorizasyon sunmaktadır. Bu çalışmada geliştirilen ve özgün bir katkı olması umulan kategorizasyona göre, epistemolojik-etik-politik düzlemlerde insan nedir sorusunun ele alınış biçimi ve verilen yanıtlar, ilk bakışta büyük bir çeşitlilik/çoğulluk gösteriyor olmasına rağmen, esas itibariyle bu arayış bir sarkacın iki uçta salınımını andırmaktadır. Bilindiği üzere, siyasal düşüncenin başlangıcı, yaygın olarak, mottoları 'İnsan her şeyin ölçüsüdür' olan Sofistler'e dayandırılır. Bu motto, burada bizim için bahsi geçen sarkacın hareketine başladığı taraf olarak ele alınmaktadır; diğer tarafta da onlardan hemen sonra gelen, siyasal düşüncede bir çığır açtı̆̆ konusunda hemen herkesin hemfikir olduğu Sokrates ve onun 'Kendini bil' öğretisi bulunmaktadır. Ve, bu makalenin önermesine göre, bu sarkacın bu ikisi arasındaki salınımı o tarihten bu yana hiç durmamıştır. İkinci olarak, bu makale “insan gerçekte nedir?” sorusunun ayrılmaz biçimde özgürleşme/özgürlük sorunsalıyla iç içe olduğunu öne sürmektedir. İnsanın 'Ben neyim' sorusuna verdiği cevap 'Ne yaparsam/ne olursa özgür olurum?' sorusuna verdiği cevapla iç içedir. Söz konusu kategorizasyonun terimleriyle, insan haddini bilince/bilirse mi özgür olur, haddini aşabilince/aşabilirse mi? Üçüncü olarak, bu makale posthümanizmin bu ikili karşıtlık arasındaki salınıma bir dokunuş olduğunu öne sürmektedir. Posthümanizm ikili karşıtlıklar, özcülük ve keskin ayrımlar karşısında konumlandığı, buna karşılık olumsallık, devinim ve geçirgenlik gibi kavramların altını çizmekte olan bir yaklaşım olarak insanı ne salt haddini aşabilmek üzerinden tanımlamaktadır ne salt haddini bilmek üzerinden; aynı zamanda da posthümanizm insanı hem haddini aşabilmek üzerinden tanımlamaktadır hem de haddini bilmek üzerinden. Bu durumda özgürlük sorunsalı biraz daha karmaşık hale gelmektedir. İnsanın özgürleşmesi ne zaman haddini bileceğine ne zaman haddini aşmaya cesaret/cüret edeceğine karar verebilmesiyle ilişkilidir.

Anahtar Kelimeler: İnsan, Hümanizm, Posthümanizm.

\section{On the Posthumanism Debate and Being Human: Between 'Human is the Measure of Everything' and 'Know Thyself'}

\footnotetext{
Abstract

In order for the debates revolving around the notion of posthumanism to be a new opening in the way we think of ourselves and attach a meaning to the world around us, we have to contextualize them within the centuriesold tradition of political thinking. For that purpose this article presents an original categorization of the different conceptualizations of 'human' epistemologically, ethically and politically and argues that despite the seeming variety and plurality of the approaches as to the defining features of human-ness, there are basically
} 
two approaches: One defines humanness with reference to the capacity of 'knowing thyself' in the Socratic sense of the term while the other defines humanness with reference to the notion of agency, in the sense of being a potent subject who knows and acts autonomously. So, in that aspect, the long history of (political) thinking looks like a pendulum going back and forth between these two approaches whose origins, in their turn, go back to the origins of the political thought itself, namely the sophists and Socrates. Secondly, it is argued in this article this quest to attach a meaning to humanness is inevitably linked with the question of freedom so that the question now becomes the question of how the human beings are to get free: once they know their limits or once they transgress them? Thirdly, since posthumanism is mostly characterized by a rejection of binary oppositions and essentialism, and an embracement of contingency and fluidity, it is argued in this article that the posthumanist answer to that question of freedom would be to underline the need for the coexistence of both capacities, namely both a consciousness about the limitations on the human capacity and also an eagerness and courage to push the limits.

Keywords: Human, Posthumanism, Humanism.

\title{
Giriş
}

\begin{abstract}
Diogenes gündüz vakti bir kandil yaktı ve yürüdü, niye böyle yaptığı sorulunca da bir insan aradı̆̆ını söyledi... Bir gün yüksek sesle insanlara seslenmiş, halk etrafinda toplanınca "Insanlarl arlyorum, pislikleri değil” diyerek değneğiyle onlara vurmuş. Hekaton bunu Anektodlar'ının birinci kitabında anlatır (Çevik 2020: 91).
\end{abstract}

Kinik Diogenes'in böyle 'tuhaf' şeyler yapmak için kendince geçerli nedenleri ve etrafında toplanan kişileri insan olarak saymamak için de kendince geçerli kriterleri vardı. Bu nedenler ve kriterler ayrıca üzerinde durulmayı hak ediyor olsa da asıl ilgi çekici ve kışkırtıcı olan, onun insanı tanımlarken başvurduğu şu cümlesi: 'sadece insanın gerçekte ne olduğunu bilene insan [denir]' (Çevik 2020: 91).

Asırlar sonra bir başka düşünür, Michel Foucault, ise verdiği bir röportajda 'her şeyin insan fikrini giderek daha da işe yaramaz hale getirdiğini' (Bejan 2020: 35) öne sürüyor ve insanın ne/kim olduğuna kafa yoranlara, bu tartışmanın en önemli tartışma olduğunu düşünenlere ancak 'felsefî̀ bir kahkahayla' karşıllk verilebileceğini iddia ediyordu:

Hâlâ insandan, [insanın] hüküm sürmesinden veya kurtuluşundan söz etmek isteyen herkesin, hâlâ insanın özünde ne olduğuna dair soru soranların, gerçeğe ulaşmak için insandan yola çıkmak isteyenlerin, buna karşılık her bilgiyi bizatihi insanın gerçeklerine yönelten herkesin ... düşünenin insan olduğunu hemen 
düşünmeden düşünmek istemeyen herkesin karşısına, bütün bu beceriksiz ve beceriksizleştirilmiş düşünce biçimlerinin karşısına, felsefî ... bir gülüşten başka bir şey çıkarılamaz (Foucault, 2001: 477). ${ }^{1}$

Bu iki zıt kutbu birlikte görmenin kışkırtıcılığı bu makalenin de çıkış noktasıdır: Bir uçta 'İnsan nedir?' sorusunu cevaplayabilir olmayı insan olmanın koşulu olarak görmek, diğer uçta insanın ne olduğu, insan olmanın ne anlama geldiği gibi soruları anlamsız, faydasız, beyhude ve hatta zararlı bir arayış olarak etiketleyip 'iptal etmek' bulunan bir kutuplaşmayı meşru bulmak zorunda mıyız? Bu iki seçenek arasına sıkışıp kalmak zorunda mıyı? Böyle sorular ise bizi, son dönemlerde insanları tam da bunlar hakkında bir kez daha düşünmeye davet etmekte olan ve giderek de yükselen bir ilgiyle karşılaşan posthümanizm tartışmalarına götürüyor. $\mathrm{Bu}$ tartışmalar bugün transhümanizm ve antihümanizm gibi kavramların da işin içine girmesiyle büyük bir çeşitliliği içinde barındırıyor ve tam da bu çeşitlilik nedeniyle hem insanın kendisi hakkındaki düşünüşünde yeni bir açılım sağlama potansiyeli sergiliyor hem de her geçen gün daha kafa karıştırıcı bir hal almaya başlıyor. Farklılaşan anlayışların bir arada bulunuşuyla bu literatür bir yandan giderek zenginleşip derinleşirken buna bağlı olarak aynı zamanda giderek karmaşıklaşıyor; ne önerdiğini ya da vaat ettiğini anlamak da anlamlandırmak da giderek zorlaşıyor.

Diogenes'in insan olmanın koşulu olarak sunduğu insanın gerçekte ne olduğunu bilmek, aslında siyasal düşünceler tarihinin özünü oluşturan meseledir. Bilebildiğimiz en eski dönemlerden itibaren insanlık, insanın "gerçekte ne olduğu" üzerine kafa yormaktadır. Hatta, bu açıdan bakıldığında insanlık tarihinin, insanın 'ne'liğine dair epistemolojik değerlendirmelerin; onlara uygun etik değerlerin, normların, ilkelerin ve bunlar üzerinde şekillenen siyasal kurumların tarihi olarak okumak mümkündür. Yani insana dair farklı kavramsallaştırmalar (posthümanizm tartışmaları da dahil olmak üzere) esasen epistemolojik, etik ve politik düzlemler arasındaki kesişimselliği, bunların

\footnotetext{
${ }^{1}$ Foucault'nun, burada söyledikleriyle hedef tahtasına oturttuğu geleneğin hümanizm olduğu aşikardır ki kendisi de aynı mülakatında hümanizmi 'on dokuzuncu yüzyılın en kasvetli ve bunaltıcı mirası' olarak tanımlayıp 'bir an önce kendimizi ondan kurtarmamız gerektiğini,' söylemekte, bu anlamda önümüzdekinin 'politik bir vazife' olduğunu da vurgulamaktadır (Aktaran Bejan 2020: 35).
} 
iç içe geçmişliğini simgelemektedir. Bu durumda, bahsettiğimiz güncel posthümanizm tartışmaları da esas itibariyle bu uzun tarihin yeni safhasıdır. ${ }^{2}$

$\mathrm{Bu}$ arka plana dayanarak bu makale posthümanizm tartışmalarının ancak kadim 'insan nedir' sorusunun geçmişten bugüne doğurmuş olduğu epistemolojik-etik-politik tartışmalarla birlikte ele alındığında ya da o bağlama oturtulduğunda bir açılım sağlayabileceğini iddia etmekte ve bunu net şekilde gösterebilmek için, siyasal düşünceler tarihinde insanın düşünülüş biçimlerine dair orijinal bir kategorizasyon sunmaktadır. $\mathrm{Bu}$ çalışmada geliştirdiğimiz ve özgün bir katkı olması umulan kategorizasyona göre, epistemolojik-etik-politik düzlemlerde insan nedir sorusunun ele alınış biçimi ve verilen yanıtlar, ilk bakışta büyük bir çeşitlilik/çoğulluk gösteriyor olmasına rağmen, esas itibariyle bu arayış bir sarkacın iki uçta salınımını andırmaktadır. Bilindiği üzere, siyasal düşüncenin başlangıcı, yaygın olarak, mottoları 'İnsan her şeyin ölçüsüdür' olan Sofistler'e dayandırılır. Bu motto, burada bizim için bahsi geçen sarkacın hareketine başladığı taraf olarak ele alınmaktadır; diğer tarafta da onlardan hemen sonra gelen, siyasal düşüncede bir çığır açtı̆̆ı konusunda hemen herkesin hemfikir olduğu Sokrates ve onun 'Kendini bil' öğretisi bulunmaktadır. Ve, bu makalenin önermesine göre, bu sarkacın bu ikisi arasındaki salınımı o tarihten bu yana hiç durmamıştır: İnsan bir her şeyi bil(ebil)mek, her şeyin tek ölçüsü olmak üzerinden tanımlanmıştır, bir ‘tek bildiğim hiçbir şey bilmiyor olabileceğimdir' öğretisi üzerinden. $\mathrm{Bu}$ uçlar bu makalede, burada açıklanan anlamları taşımak üzere, haddini bilmek ve haddini aşmak olarak adlandırılmaktadır. Başka deyişle insanın farklı düşünülüş biçimlerinin ele alınış biçimlerinin bu iki kategoriye denk düşecek şekilde süzülebileceği, insanı gerçekten insan yapan özelliğin ya haddini bilmek olarak ya da haddini aşabilmek olarak formüle edilegelmiş olduğu öne sürülmektedir. Hayli ilginç şekilde, başka bakımlardan birbirlerinden epey farklı olan düşünce akımları, gelenekler ve teoriler, bu gözlükten bakıldığında aynı tarafta gözükmektedir. Bu ilginç tespitin aynı

\footnotetext{
${ }^{2} \mathrm{Ki}$ zaten posthumanizmin kendisi de aslında ikili karşıtlıklara, keskin sınırlara ve sabit tanımlara itirazla ve bunlar yerine geçişkenliğe, olumsallığa ve devinime yapılan vurguyla şekillenen bir literatürdür. İleride de vurgulanacağı üzere posthümanizm, hümanizmi aynı anda hem epistemolojik hem etik hem de politik olarak sorunlu bulmaktadır. Bu nedenle bu makalede insana dair farklı kavramsallaştırmalar bu üç alan arasında, Gramscian bir bakışla, ontolojik değil metodolojik bir ayrım gözetmektedir.
} 
zamanda özgün bir tespit olduğu ve insana dair düşünüşe bir katkı niteliği taşıdığı öne sürülebilir. İlerleyen bölümler bu gruplandırmanın hangi düşünce akımlarını bir araya ve/veya karşı karşıya getirdiği örneklerle ortaya koyacaktır.

İkinci olarak ve devamla, bu makale “insan gerçekte nedir?” sorusunun ayrilmaz biçimde özgürleşme/özgürlük sorunsalıyla iç içe olduğunu öne sürmektedir. İnsanın 'gerçekten' insan olabilmesi en başından itibaren ve günümüzde de özgürlügün önündeki engellerin neler olduğuna dair bir tartışmayla birlikte yürümektedir: İnsanın insan olmasının önündeki engel özgür olmamasıdır, ya da insan ancak özgür olduğunda insandır. İnsanın 'Ben neyim' sorusuna verdiği cevap 'Ne yaparsam/ne olursa özgür olurum?' sorusuna verdiği cevapla iç içedir. Yukarıda özetlenen kategorizasyonun terimleriyle konuşacak olursak insan haddini bilince/bilirse mi özgür olur, haddini aşabilince/aşabilirse mi? Bu soruya verilen farklı yanıtları gördüğümüzde ise aynı zamanda insanın farklı tanımlarına da ulaşmış oluyoruz.

Üçüncü -ve yine bağlantılı- olarak, bu makale posthümanizmin bu ikili karşıtlık arasındaki salınıma bir müdahale olduğunu öne sürmektedir. Yukarıda posthümanizmin ikili karşıtlıklar, özcülük ve keskin ayrımlar karşısında konumlandığı, buna karşılık olumsallık, devinim ve geçirgenlik gibi kavramların altını çizmekte olduğu belirtilmişti. İlerleyen bölümlerde de posthümanizmin postyapısalcılık, feminizm, postmodernizm ve postkolonyalizmin meydan okumalarından beslenen ve onlara eklemlenen bir yaklaşım olduğunu görmüş olacağız. O zaman açık ki, bu bağlantılarının konumlandırmasıyla posthümanizm, insanı ne salt haddini aşabilmek üzerinden tanımlamaktadır ne salt haddini bilmek üzerinden; aynı zamanda da posthümanizm insanı hem haddini aşabilmek üzerinden tanımlamaktadır hem de haddini bilmek üzerinden. Bu durumda özgürlük sorunsalı biraz daha karmaşık hale gelmektedir. İnsanın özgürleşmesi ne zaman haddini bileceğine ne zaman haddini aşmaya cesaret/cüret edeceğine karar verebilmesiyle ilişkilidir. ${ }^{3}$

${ }^{3} \mathrm{Bu}$ durumda, Foucault'nun hümanizm reddiyesi bir yanda tartışmaya açık duruyor olsa da onun tarihsellik kavramına bu kadar önem vermekte haksız olmadığını da söyleyebiliriz. Çünkü onun bu kavramla dikkat çekmek istediği, çok temel bir meseledir: 'İnsanın gerçek tanımı' ya da 
Bu durumda bu yazı son olarak şunu öne sürmektedir: insanı tanımlayan insanın gerçekte ne olduğunu bilmek değil, daha ziyade insanın gerçekte ne olduğunu bilmeye, bulmaya ve ögrenmeye çalışmaktır. Bu, insanın, oluşu tamamlanabilen bir varlık değil, hep olma/oluş halinde bir varlık olduğunun kabul edilmesini de beraberinde getirir. $\mathrm{O}$ zaman, 'İnsan nedir?' sorusunu sormaya hala devam ediyor oluşumuz ve hala tek/kesin bir cevap bulamayışımız ise, çözmemiz gereken bir sorun değil, aslında tam da olması gerekendir. Buradan bakıldığında posthümanizm tartışmaları insanın binlerce yıldır sorduğu 'Ben kimim, insan nedir' gibi sorulardan vazgeçmişliğinin bir ifadesi değil, gerçekten insan olma(yı öğrenme) çabasının yeni bir aşamasıdır.

$\mathrm{Bu}$ çalışmada, bu önermelere uygun olarak, önce insanın kendini arayışının yolunun nasıl aynı zamanda özgürlüğü/özgürleşmeyi aramaktan geçtiğini ve bu yoldaki uğrakları göreceğiz ve posthümanizm tartışmalarının da bu yolculuğun şimdiki durağı olduğunu ama son durak olmadığını öne süreceğiz. Ve bu durumun mutlaka olumsuz bir şey olmadığını önereceğiz, yani insanın kendini arama/bulma yolculuğunun, güzergahında bazen ulaşması, bazen geri dönmesi, bazen de yeniden yola koyulmak üzere harekete geçmesi çok zor durakları olan bir yolculuk olmasının; üstelik bir de bu zorlu yolculuğun bir varış noktası/sonu olmayan bir yolculuk olmasının. Bu bakış açısıyla, posthümanizmi bir kopuş değil süreklilik ilişkisi içerisinde görmeyi tercih edeceğiz. Hümanizmin özgürlük/özgürleşme tartışmasını öncesi ve sonrasıyla bağlamsallaştırarak şu sorunun peşinden gideceğiz: İnsan hangi engeli aşarak özgürleşir ve böylelikle 'gerçek insan' olur? Önce yolculuğun posthümanizme kadarki kısmına bakacağız, sonra şu anki durumda posthümanizmin kurtulmamız gereken şey nedir sorusuna verdiği yanıtın diğer yanıtlarla olan bağını ortaya koymaya çalışacağız. Bunu yaparken, yukarıda belirtildiği gibi, ne bunu bu arayışın nihayet sona erişinin nişanesi olarak alacağız ne de Francis Fukuyama'nın (2002) bir zaman yaptığı gibi

gerçek/makbul/normal insan' tanımı asla sabit olmayıp çağlar boyunca hep değişmiştir, hala da değişmektedir. 2018 yılında Pekin'de düzenlenen Dünya Felsefe Kongresi’nin tema olarak 'İnsan olmayı öğrenmek' başlığını seçmiş olması bu duruma hayli sembolik güncel bir örnek sunmaktadır. Foucault'nun bu bağlamdaki daha da büyük katkısı, aslında, insan/insanca olan nedir, kimdir gibi sorulara verilen yanıtlardaki değişimlerin asla var olan iktidar ilişkilerinden ayrı ve bağımsız olarak okunup anlaşılamayacağını hatırlatmış olmasıdır. İktidar ilişkilerine dair bir sorgulama dolayımıyla, doğal olarak, insanın ve özgürlüğün farklı düşünülüş biçimleri ayrılmaz biçimde iç içe geçmiş durumdadır. 
posthümanizmi 'en tehlikeli fikir' olarak göreceğiz. Posthümanizmi insanı yüceltmeyen, kibirsiz hümanizm olarak konumlandırmaya çalışacağız. Onu, insan olmayı öğrenmek konusunda şu anda bulunduğumuz ve buradan nereye doğru gidebileceğimizi düşünmemizi sağlayan durak olarak düşünmeyi tercih edeceğiz.

\section{İnsan (Gerçekte) Nedir? Her Şeyi Bilen Mi Haddini Bilen Mi?}

Sofistler mi Sokratik metodun ilk temsilcileriydi yoksa Sokrates'i mi bir sofist olarak görmek gerekir? Bu sorunun cevabı hakkında bir görüş birliği bulunmuyor. Ancak bu, Sokrates'in sofistlere önemli bir müdahalede bulunmuş olduğunu görmemize engel değil. Sofistler retorik sanatını iyi icra eden kişinin kendi doğrularını diğerlerince de kabul edilebilir hale getirebileceği iddiasının taşıyıcılarıydılar. Onların arayışlarının adresi doğrunun, iyinin, adil olanın sabit ve evrensel geçerliliği olan bir tanımı değildi, zira onlara göre bu mümkün değildi; bunların tek kararlaştırıcısı, tek ölçütü insanın kendisiydi. Her şeyin ölçüsü insandı ya da farklı bir tonlamayla insan her şeyin ölçüsüydü. Burada evrensel doğrular yerine göreceliliğin vurgulanmakta olduğu açıktır.

İlk bakışta sofistlerle aynı yolun izliyormuş gibi görünen Sokrates aslında bambaşka bir yol açmıştır. Onun müdahalesinin anahtarı düşüncesinin kalbinde yer alan bir ikilemde yer almaktadır: Nasıl olur da zihinlere kazınmış cümlesi 'Tek bildiğim hiçbir şey bilmediğimdir' olan, en sık yaptığı şey, kendine özgü yöntemiyle, bildiğimizi sandığımız şeyi bilmiyor, bilmediğimizi sandığımız şeyi de biliyor olabileceğimizi gösterip bizi sarsmak olan Sokrates'in bir yandan da en büyük öğüdü 'Kendini bil' olabilir? Bu durum ilk bakışta tuhaf gibi görünse de aslında değildir. Çünkü Sokrates'in bizi kendimiz hakkında bilmeye davet ettiği şey, sınırlarımızdır; ortaya çıkarıp belirginleştirmek istediği şey bilişimizin, anlayışımızın tam ve mükemmel olamayacağına ve/veya olmayabileceğine dair bir farkındalıktır. İnsanın, bildiği(ni zannettiği)ne çok da güvenmemesi gerektiğgi, onun bilişini, görüşünü, anlayışını aşan evrensel doğrular olduğu gerçeğini fark etmesi Sokrates'e göre insanca yaşamın anahtarıdır. Bunun nedeni ise ona göre çok açıktır: Çünkü insan kendi bildiğinin tek/evrensel doğru/hakikat olduğunu düşünürse hakikat arayışı sonlanır. Oysa 
Sokrates'e göre, etik yani insanca bir yaşam ancak hakikat arayışıyla karakterize olan bir yaşamdır ve 'Üzerinde düşünülmeyen hayat, yaşamaya değmez.'

Sofistleri ve Sokrates'i siyasal düşüncenin başlangıcına yerleştirmek konusunda yaygın bir görüş birliği olduğuna göre, yukarıda da belirttiğimiz üzere, aslında insanın kendisi hakkında düşünüşüne dair her şey böyle başlamıştı diyebiliriz. Yani aslında insanın epistemolojik-etik-politik bir kavram olarak macerası daha yolun en başında hemen bir kavşağa çıkmıştı: İnsan her şeyin merkezi, tek kriteri, tek ölçüsü müdür yoksa kendi sınırları/sınırlılıkları hakkında düşünen, bunların farkında olan ve ne gibi sorunlar çıkarabileceğini bilen bir varlık olmak, hiçbir şey bilmiyor olabileceğini, hatta bilip bilmediğini bile bilemiyor olabileceğini bilmek mi insanı insan kılan özelliktir? İşte sarkaç böylece bu ikisi arasında yüzyıllarca sürecek salınımına başlamıştı.

\section{İnsan: Haddini Bilen}

Sokrates'le başlattığımız insanın kendini tanım(lam)asında bu belli bir anlamda haddini bilme öğesi siyasal düşüncede bir süre baş rolde olmaya devam etmiştir. Sokrates'in sevgili öğrencisi Platon'un mağara alegorisiyle anlatmaya çalıştığı şey de insanın kendi duyu organlarının ona 'hakikat'i vermiyor oluşuydu. Büyük çoğunluğumuz o karanlık mağarada çok az hareket kabiliyetine sahip şekilde yaşayan, yarıktan sızan 1şıktan dolayı duvarda oluşan gölgeleri gerçek sanan, nasıl bir yanılgı içerisinde olduğuna dair ise hiçbir farkındalığı olmayanlardık. Gerçeğe erişmek için çok meşakkatli bir yola girmek, hem karanlığa alışmış gözlerimizin 1şığa doğru yürürken kamaşıp yanmasına hem de kendi yanılmışığımızla yüzleşip kabullenmenin acısına katlanmak zorunda olan ve bu zorlukları göğ̈̈slemeye pek de gönüllü olmayanlardık. Neticede episteme, hakikatin bilgisi, bu dünyaya ait bir şey değildi, onların kendine ait başka bir evreni vardı.

İnsanı aşan ve öyle hemen, kolayca, zahmetsizce ve mutlak kesinlikle erişemeyeceği evrensel doğrular olduğu fikri Helenistik dönem Stoacılığına, oradan da Hristiyanlıkla yoğrulmuş orta çağ siyasal düşüncesine de sirayet etmiştir. Örneğin, Stoacılığın büyük ismi Seneca'nın Ruh Dinginliği Üzerine konuşurken sürekli olarak 
logosun kendine özgü yasalarının ardında yatan zorunluluk ilkesini hatırlatışı bu bağlamda anlamlıdır. Bu hatırlatmayla düşünür insanlığı iki büyük yanlıştan kaçınmaya davet etmektedir. Bunlardan birisi hiçbir şeyi değiştiremeyeceğini düşünmekse diğeri de her şeyi değiştirebileceğini zannetmektir. İnsan ancak logosun evrensel doğrularının oluşturduğu zorunluluk ilkesini anladığı ve onu kabullendiği ölçüde özgürdür. Özgürler ve köleler arasındaki hiyerarşik ilişkinin tek kriteri budur, gerçek insan - yani köle olmayanlar- logosun zorunluluk yasalarını fark etmiş, anlamış ve idrak etmiş olandır. Dışarıdan bakıldığında köle gibi görünen birisi Seneca'nın tanımına göre özgür/insanca bir yaşama sahip olabilir ya da tam tersi, dışarıdan bakıldığında kral tahtında oturduğu için özgür gibi görünen birisi aslında bu tanıma göre bir köle olabilir. Hatta kişinin kendisi de kendi durumunun farkında olmayabilir, o nedenle Seneca'ya göre ruh dinginliğine erişmek için yapılması gereken, 'bütün zaafların ortaya konması' dır (87). ${ }^{4}$

Orta çağ düşüncesine damga vurmuş, yüzyıllar boyunca hâkim görüş olarak kalmış görüşlerin sahibi olan St. Augustin de insanın bu dünyadaki varlığının ve sürdürmekte olduğu bireysel/toplumsal/siyasal yaşamının tamamıyla Tanrı iradesinin neticesinde ve ona uygun olarak vuku bulduğunu, var olan her şeyin -insanın ve çevresinde gördügü/göremediği her şeyin- Tanrı tarafından ve onun dilediği şekilde yaratıldığını, dolayısıyla sadece iyiliğin değil kötülüğün de o istediği için ve o istediği sürece var olacağını söylediğinde gerçek insan bir kez daha, haddini bilmek anlamında kendini bilmek üzerinden tanımlanmış oluyordu. İnsan, yaptığının doğru/yanlış, iyi/kötü, adil/gayrıadil olduğundan asla emin olamayacak bir varlıktı, buna karar vermesini mümkün kılacak kriterleri haiz değildi; son söz, bu kez Tanrı kelamı biçimindeki evrensel doğrulardaydı.

$\mathrm{Bu}$ zincir nerelerde kopmaya başlamış olabilir? Doğruların insanın üstünde olduğu, insanın kendisini aşan/kendisi dışında bir yerlerde bulunan doğrular

\footnotetext{
${ }^{4}$ Aynı geleneğin bir başka büyük temsilcisi olarak Cicero, bugün doğal hukuk nosyonunun kurucusu olarak kabul edilmesine yol açan yaklaşımında devletlerin/yönetimlerin iyi/adil/doğru olarak tanımlanabilmesi için tek koşulun o devletlerin yasalarının ve cumhuriyetin yurttaşlarının kararlarının daimî surette logosla ahenk içinde olma zorunluluğuna dikkat çekmektedir. Doğa yasasıyla, evrensel doğrularla uyumlu olmayan hiçbir görüş/karar/yasa/eylem doğru ve adil olamaz. İnsan doğa yasasının ona ne söylediğine kulak kabartmak zorundadır.
} 
karşısındaki konumunu düşünerek kendi varlığını tanımlaması gerektiği düşüncesi ne zaman, nasıl yerini başka bir zihniyete vermeye başlamış olabilir? Bu ikame yaygın biçimde Rönesans'la ilişkilendirilse de yukarıda da değinildiği gibi aslında kökleri çok daha eskilere, siyasal düşüncenin başlangıcındaki 'insan her şeyin ölçüsüdür' ilkesine dayanmaktadır.

\section{İnsan: Her Şeyi Bilen / Her Şeyin Ölçüsü}

Çoğu zaman Rönesans dönemi resim sanatında perspektif kullanımının yerleşikleşmesi örneğiyle de açıklandığı üzere bu dönemin (çoğu zaman modernitenin başlangıcı da Rönesans'la özdeşleştirildiği için, modern çağın) ayırt edici özelliği artık esas olanın dünyayı insanın görme biçimi olmasıdır. Dünyaya insanın gözünden bakılmaktadır, oradan nasıl görünüyorsa dünya öyledir. Nitekim, bilindiği üzere, daha önce var olmayan bir kategori olarak 'birey' kavramının doğum tarihi de zaten bu döneme denk düşmektedir. Aslında Rönesans’tan daha önce Padovalı Marsilius'un yaptığı adalet ve bununla bağlantılı medenîlik tanımı, insanı her şeyin merkezine yerleştiren perspektifin erken bir habercisi gibidir. Marsillius, medeniyeti/medenî toplumu temel insanî ihtiyaçları karşılanmamış durumda kimsenin olmadığı toplum olarak tanımlamıştır. İnsan, doğası gereği doyurucu ve yeterli bir yaşam sürdürmeyi arzu eden bir varlıktır. O zaman bu, herhangi bir toplumda bütün insanlar için mümkün olduğunda/kılındığında, bu insanlar kendi doğalarını gerçekleştirmiş ve/veya doğalarına uygun bir yaşama sahip olacaklardır. Bu ise, doğru, iyi, güzel, adil, ahlakî gibi sıfatları hak eden bir yapının tanımıdır.

Yeterli ve doyurucu bir yaşamın tanımının salt insan ihtiyaçları temelinde yapılması düşüncesi, ilerleyen zamanlarda bu ihtiyaçların neler olduğuna da bireyin bizatihi kendisinin -sadece ve mutlaka kendisinin- karar vermesi, zaten aslında başka türlüsünün de düşünülemez olduğu fikriyle birleşecektir. Sıradaki bu kapıyı açan Thomas Hobbes, o kapıdan girip başka bir koridora çıkan ise John Locke olacaktır. Leviathan'da 'En kötü yönetim hiç yönetimin olmamasından iyidir' görüşünü israrla savunduğu ve buna dayanarak ne türden bir gerekçeyle olursa olsun devlete itaatsizlik 
gibi bir seçeneği tamamen reddettiği için otoriter yanı çoğu zaman daha fazla ön plana çıkan Hobbes'un aslında devleti, onun varlığını ve egemenliğini sonuna kadar savunuyor olmasının arkasında en az diğer önceliği kadar sarih olan başka bir örnek yatmaktadır: bireyin mutluluğu. Hobbes'un kurduğu zincirin halkalarını takip edersek karşımıza şöyle bir manzara çıkar: insanın/bireyin mutlu bir yaşam sürebilmesi, Marsillius'un da dikkat çektiği üzere, kendi doğasıyla uyumlu bir yaşam sürüyor oluşuyla mümkündür. Ve insan doğası Hobbes'a göre aslında son derece basit bir içeriğe sahiptir; çünkü bütün insan davranışı iki temel gücün kontrolü altındadır: iştiha ve kaçınma. Neye iştihayla yaklaşacağı ve/veya neden kaçınacağı ise yalnızca kişinin bireysel olarak yapacağı -ve zaten sadece kendisinin yapabileceği- bir hesap ve akıl yürütmeyle belirlenir. Buradaki temel kriter insanın bu dünyadaki var oluşunu güçlendirecek/zayıflatacak faktörlerdir; yani doğal olarak insan kendisini güçlü kılacak şeyi ister ve onu iyi/doğru olarak adlandırır; zayıf düşürecek olandan da kaçınır ve onu da kötü/yanlış olarak adlandırır. Bu da da zaten Hobbes'a göre insana özgü doğal hak kavramının tanımıdır.

$\mathrm{Bu}$ şekilde doğrunun ve yanlışın, iyinin ve kötünün kendi aklıyla yaptığı hesaplamaya dayalı olarak tek belirleyeni olarak ilan edilen insan, Hobbes'un hikayesinin devamında devletin de kendi iyiliği açısından iyi bir şey olacağına karar verdiği için onu da kendisi yaratacaktır. Bu durumda, orta çağ öğretisinden tamamıyla farklı olarak devlet tanrı öyle uygun gördüğ̈̈ için var olan, onun iradesiyle oluşmuş bir şey olmaktan da çıkmıştır. Neyin olması gerektiğine yine insan, yine kendi bakışından karar vermiştir. John Locke'un Aydınlanma düşüncesinin tohumunu oluşturan tabula rasa kavramı da bunu pekiştiren bir vurguyla insanın, kendisi için geçerli olacak etik kuralları kendi deneyimine ve gözlemlerine dayanarak oluşturacağını, dünyaya geldiğinde boş bir levha olan insan zihnini dolduracak şeylerin ancak bunlar olacağını anlatan bir kavramdır. Toplumsal sözleşme teorisinin ayrıksı ismi Jean Jacques Rousseau pek çok konuda diğerleriyle aynı fikirde olmasa da onun da insanın doğru olanı bulmak konusunda genel irade sergileyeceğine dair inancı benzer bir vurgu taşır. 
Locke ve Rousseau'nun Aydınlanma'nın kilit düşünürleri olması, bunları düşününce şaşırtıcı değildir.

Aydınlanma'nın insana, onun aklına, iradesine ve yapabileceklerine duyduğu güvenin onlarınkinden epeyce farklı yorumları da Marx ve Bakunin örneklerinde sosyalist ve anarşist gelenek içerisinde ortaya çıkmıştır. Bu kez insan, mevcut düzeni tümüyle ortadan kaldıracak, yerine tamamen farklı ilkelere ve değerlere dayanan ideal düzeni getirecek devrimci öznedir. Bu, yükselmiş bilinciyle neyin olmaması gerektiğini, onun yerine neyin kurulması gerektiğini, kendisinin ne olduğunu/olmadığını ve ne yapma(ma)sı gerektiğini bilen öznedir. Örneğin Bakunin, bir devrimle ortadan kaldırılacak devletin yerini dolduracak olanın 'anarşist ahlak' olduğunu söylediğinde insanların beraber ve özgürce yaşamak için başka hiçbir otoriteye ihtiyaç duymaksızın gerekli olan kuralları bildiklerini öne sürmektedir.

Haddini bilen insan yerine her şeyi bilen/her şeyi yapabilecek güce sahip olan/her şeyin ölçüsü iinsan figürünü bir takım özsel niteliklerle tanımlayıp yücelten yaklaşım on dokuzuncu yüzyıl boyunca sarsılmaz bir konuma sahip olmuştu. Erich Fromm’un 'mesihçi vizyon' olarak adlandırdığı bu yaklaşımla yirminci yüzyıla girildiğinde 'doğaya egemen olmuş, savaşın kökünü kazıyacak insanlığın gelişimi için bir araç olarak maddi bolluk üretecek insan'a (Fromm 1994: 18) dair fikirlere ve umutlara duyulan inanç hâkimdi. Fakat bu inancı çeşitli açılardan sorgulayan ve aslında hiç eksik olmayan meydan okumalar da bir kez daha belirgin şekilde çoktan ortaya çıkmıştı. Sarkaç bir kez daha diğer tarafa doğru- haddini bilmeye doğru- salınmaya başlamıştı.

\section{İnsan: Kendini Bilen / Haddini Bilen (İkinci Bölüm)}

Kuzey Amerika geleneğindeki meşhur çakal söylencesine göre, çakal ne zaman nasihate ya da ilhama ihtiyaç duysa uzun uzun ıkına sıkına oracı̆̆a dışkısını yapar. Ortaya çıkan ürün, diyaloğun ve icatların devam edebilmesi için ihtiyaç duyulan yaratıcı güç olur (Glazier 2018: 173).

Modern çağa damgasını vuran bu insan anlayışına, yani, insanın doğruyu yanlıştan, iyiyi kötüden ayırmak konusundaki -hiç kimseye ve hiçbir şeye borçlu 
olmadığı- müthiş potansiyeli, kapasitesi, aklı ve iradesi gibi bir takım özsel nitelikler atfedilerek yüceltilmesine, en etkili meydan okumalardan biri kadınlardan geldi. Kadınlar özellikle toplumsal sözleşme kuramının merkezinde yer alan rasyonel, çıkarcı, ben-merkezci birey ve onun yanı sıra hak, özgürlük, akıl, irade, birey, sözleşme, egemenlik, görev, yükümlülük, itaat, isyan hakkı gibi kavramların kadınları tümden göz ardı ederek erkeklerin gözünden ele alınmakta olduğunu fark etmekte ve dile getirmekte neredeyse hiç vakit kaybetmemişlerdi: Bütün bu tartışmalarda bahsi geçen ve alabildiğine yüceltilen insan 'erkek’ti! Örneğin Mary Astell İngiltere'de 1700 y1lında yayınlanan Evlilik Üzerine Düşünceler (Some Reflections upon Marriage) kitabında ev içi iktidar ile siyasal iktidar arasındaki türdeşliği göstermeyi amaçlamış ve otoritenin yönetilenlerin rızasından türediği anlayışını savunanları riyakârlıkla itham etmiştir (O’Brien 2009: 13). Ona göre hem siyasal alanda hem de evlilikte gönüllü olarak taraf olunduğu öne sürülen sözleşmeler esasında gelenekselleşmiş boyun eğdirme yöntemlerinin iki formudur sadece. Mary Wollstonecraft da 1792 y1lında yayınlanan Kadın Haklarının Gerekçelendirilmesi başlıklı kitabında erkeklerden farklı olarak kadınların durumunda edep ve terbiyenin nasıl hep ahlaktan daha önemli ve öncelikli tutulduğunu hatırlatmaktadır. Etik tartışmalar kadınlar için değildir, kadınlardan beklenen, edepli/terbiyeli olmalarıdır. Wollstonecraft kadınların ahlaka yaklaşımlarını "toplumsal açıdan uygunluk/münasiplik" kriterlerinin pençesinden kurtarmak gerektiğini öne sürer; kadınların zihinsel ve ruhsal iyiliği ve refahı ancak böyle mümkün olacaktır. Wollstonecraft'ın sözünü ettiği şey sadece var olan eğitim sisteminin eksiklerini analiz edip onları gidermeye çalışmak değildir. Kadın kimliğinin, kadının bir özne olarak kuruluşunun psikolojik temelleri de derinden analiz edilmelidir. Burada aslında Wollstonecraft, insanın düşünülme biçimini de derinden etkileyen çok önemli bir soru sormaktadır: Zihni cinsiyetlendiren nedir? Kadınların sadece özel alanda itibarlı olmanın ve hürmet görebilmenin kurallarını öğrenmelerine ve bu kurallara sıkı sıkıya itaat etmenin hayattaki en önemli şey olduğuna inanmalarına neden olan kültürel etkiler nelerdir? 
Kadınların bu müdahalesi, Aydınlanma ile etkili olmaya başlayan insan-merkezli dünya görüşüne ve herkesin üzerinde anlaşmış gibi göründüğü tam bağımsız-özerk insan tanımına 'İnsan nedir?’ sorusunu yeniden sorarak yapılmış ilk müdahaledir ve bu nedenle çok önemli bir dönüm noktasıdır. $\mathrm{Bu}$ anlamda güncel posthümanizm tartışmalarının kökleri de esasen buraya uzanmaktadır. Kadınların müdahalesi elbette son olmayacak, ilerleyen dönemlerde farklı sorular/sorgulamalar gelmeye devam edecektir. Bunlar arasında, bugün en az bilinenlerden biri olmasına rağmen aslında çok etkili olmuş olanların başında Max Stirner'ın eleştirisi gelmektedir. Stirner felsefesi Nietzsche'nin "üst insan" prototipine birebir benzerlik gösteren 'biricik ben' felsefesidir. Ona göre tanrı da devlet de sadece kendi çıkarları için çalışmaktadırlar; öyleyse insanın da sadece kendi çıkarlarını gözeterek ve hiç kimseye bağlı olmaksızın kendi için çalışması, kendi benini oluşturması gerekmektedir. İnsanın oluşturması gereken ve bireyselliğini bu sayede yapılandıracağı şey, işte bu 'biricik ben'idir. Biricik ben felsefesi Aydınlanmacı hümanizmin, onun anarşist versiyonu da dahil olmak üzere tümden reddedilmesidir (Newman 2001: 99-127). Stirner'a göre bu hümanizm Tanrı yerine insanı koymuş, böylece kendisi de yeni bir din olmuş, eleştirdiği şeyi yapar hale gelmiştir. İrade, akıl, düşünce, sevgi, iyilik, karşılıklı yardımlaşma, insanın özsel nitelikleri olarak görülmüş, insan her şeye kadir, kutsal, mükemmel, sonsuz, kısaca Tanrı haline gelmiştir (Newman 2001: 103). Stirner'a göre belli özelliklerin ve niteliklerin insanın özsel nitelikleri haline getirilmesi, bu nitelikler kendisinde bulunmayan kimseleri yabancılaştırmıştır. Çünkü bu şekilde tıpkı daha önce tanrı karşısında insanın değerinin düşmesi gibi somut bireyin de bu 'kusursuz varlık olarak insan’ karşısında değeri düşmüştür (Newman 2001: 104). Ona göre özsel bir insan doğası yoktur, bu bir inşadır; insanın var oluşunun temelinde bir 'özsel nitelikler' kümesinden çok bir hiçlik, tanımlanamayan bir şey bulunur. Bundan bir şey yaratmak bireyin kendisine bağlıdır (Newman 2001: 107). Halbuki Stirner hem anarşizmin hem de marksizmin/sosyalizmin herkesin içinde özsel bir insanlık çekirdeği olduğunu ve insanların buna göre yaşaması gerektiğini söyleyerek herkesi 'insani varlıklar olmaya' ve belli bir insan özüne uymaya zorladığını iddia etmektedir. Bu özle ahenk içinde olunmaması gayrı-insani sayılmaya yol açacaktır. Böylelikle ‘insan’ artık insanların 
yargılandığı ve cezalandırıldığı yeni kıstas ve bir tahakküm aracı olmuştur; farklılığ1 mahkûm eden yeni norm 'insan özü'dür (Newman 2001: 109). Stirner'in açtığı kapıdan daha sonra Nietzsche girecek, biricik ben felsefesinden izler taşıyan Übermensch kavramını geliştirecektir. ${ }^{5}$

Her şeyi bilen/her şeyi yapabilecek güce sahip olan insan figürünün bir takım özsel (sabit, evrensel) niteliklerle tanımlanıp yüceltilmesinin nelere yol açabileceğini ve açtığını- tartışmaya açan başka bir eleştirel müdahale Frankfurt Okulu'ndan gelmiştir. Bilindiği üzere, Teodor Adorno ve Max Horkheimer Aydınlanma'nın Diyalektiği’nde akıl, mantık ve düşüncenin insanın özü olarak yüceltilmesinin bilimsel bilginin kendisinin bir tabu haline gelmesine yol açtığını, bunun ise eleştirel düşüncenin önünü tamamen kapattığını öne sürerek etkileyici bir tartışma başlatmışlardır. Bunun sonucu da insan doğasının eleştirel düşünce yerine 'araçsal akıl' üzerinden tanımlanması olmuştur. İnsana özgü normal davranış, eylemlerinin ahlakî anlamı ve sonuçlarına dair düşünmek değil, salt sonuç odaklı hesap yeteneği olarak tanımlanmıştır. İnsan sebep-sonuç ilişkilerini kurabilen, belirlenen sonuca ulaşabilmek için en verimli araçları kullanabilen varlıktır. İnsanın bu özelliklerle tanımlanmasının neye yol açtığını Adorno ve Horkheimer tek sözcükle ifade eder: Auschwitz. Eserlerini Frankfurt Okulu düşünürlerinden etkilenerek yazmış olan Hannah Arendt tüm çalışmalarındaki temel kaygısını İnsanlık Durumu'nda şöyle ifade eder: 'Yaptığımız şey hakkında düşünmek.' İnsan, yaptıkları hakkında düşünmeyi bırakmıştır ve ona göre olabilecek en kötü şey kötülük yapan insanların artması değil yaptığının iyi ya da kötü olduğu hakkında düşünmeyi bırakmış olmasıdır.

Bu eleştirel yaklaşımlara verilebilecek örnekler elbette çoğaltılabilir. Ancak bizim amacımız bakımından, yani posthümanizmin insana dair, hümanizmi ve ona farklı açılardan yöneltilen sert eleştirileri içeren çok zengin ve derin bir eleştirel birikimin üzerinde yükselmekte olduğunu gösterebilmek bakımından bu zikredilenler yeterli sayılabilir. Bu düşünsel-tarihsel arka plan ve posthümanizm birlikte ele alındığında

\footnotetext{
${ }^{5}$ Bizim burada değinmediğimiz Nietzsche'nin posthümanizm tartışmasındaki yerine dair bir tartışma için bkz. Paul O'Mahoney (2020). "Nietzsche's Posthuman Political Vision," The European Legacy, 25(1): 119.
} 
aslinda ne olursa olsun/ne olmuş olursa olsun insandan yine de umudu kesmemenin bir ifadesi olarak görülebilir. O zaman aslında başta kurduğumuz ikili karşıtlık da bütün bu tartışmaların birikimiyle varılan bir yol ayrımıdır ve son tahlilde bu birikim bugün hem eski soruların yeniden sorulmasını hem de yenilerinin ele alınmasını zorunlu kılmıştır. İnsan olmanın yolu hangisinden geçmektedir: İnsanın gerçekte ne olduğunu bilmekten mi, yoksa insana dair düşünmeye devam edenlere gülüp geçmekten mi? Posthümanizmin bu soruya cevabı açıktır: Hiçbiri! Peki, insanı insan yapan şey her şeyi bilen/kuran fail olması mıdır, haddini biliyor olması mı? Posthümanizmin bu soruya da cevabı açıktır: Hiçbiri ve her ikisi de! Posthümanizm, yukarıda da belirtildiği gibi hem özgürlüğün hem de insanın bir nitelik olarak değil bir süreç olarak, süreklilik gösteren bir var oluş hali olarak düşünülmesidir. İnsan sürekli var oluş halindedir, çünkü insan olabilmek için özgürleşmesi gereken şeyin ne olduğu sorusuna verilen yanıt sabit olmayıp sürekli değişmektedir.

\section{Posthümanizm}

Posthümanizmin temel iddiası hümanizmin hem epistemolojik hem etik hem de politik olarak itiraza açık olduğudur (Braidotti 2013: 24). Postmodernist, feminist, postyapısalcı ve postkolonyalist kuramların da ikna edici biçimde göstermekte olduğu üzere, hümanizm bazı ön kabuller ve varsayımlar üzerine kuruludur. En başta, "hümanizmin hegemonik öznesi olan 'Standart Adam' çok tanıdıktır: 'beyaz-Avrupa kökenli-heteroseksüel-maskülen-engelsiz/sağlıklı bedene sahip Adam' (Kumm et al. 2019: 342). İnsan/lık statüsünün temel belirleyici normları nadiren bunların altında ya da dişında olmuştur (Braidotti 2013: 342). Avrupa-merkezci bir yaklaşımla tanımlanan bu 'Standart Adam' rasyonalite, bilinçlilik, öz farkındalık, medenilik, kamusallık gibi nosyonları uhdesinde barındıran bir evrensel kimlik olarak alınmış, böylelikle Sofist Protagoras'ın ünlü 'insan her şeyin ölçüsüdür' sözü özü itibariyle Standart Adam her şeyin ölçüsüdür' anlamına gelmeye başlamıştır. (Kumm et al. 2019: 342).

Yukarıda bahsedilen kuramlar tarafindan bu Avrupa-merkezci evrenselliğe meydan okunması, hümanizmin kıyasıya eleştirisine ve sonuçta hümanizm karşıtlığına 
dönüşen bir sorgulamanın da başlamasına yol açarken aynı zamanda pratik olarak da başka bir süreç daha yaşanıyordu: İnsan, kendi eliyle geliştirdiği teknolojinin yaşamını kolaylaştıracağını düşünürken dünyanın her yerinde çalışan insanlar giderek daha da fazla çalışmaya, çalışmak üzere iş bulamayan insan sayısı da giderek artmaya başladı; sosyo-ekonomik ve politik eşitsizlikler ve sömürü giderek derinleşirken insanın arzu edilen, ideal dünyayı hayata geçirmek konusundaki iradesi, eylemliliği ve hatta bu konudaki potansiyeli, gerçekleşmesi giderek imkansızlaşan bir hayal olmaya başladı; doğaya verilen tahribatın neticesinde ortaya çıkan ekolojik sorunlar çeşitli doğal afetler ve salgınlarla görünür olurken insanın bunları engellemek, geriye döndürmek ya da kendini bunlara karşı korumak konusundaki çaresizliği düşündürücü ve hatta ürkütücü boyutlara ulaştı. İki dünya savaşı, nükleer silahlanmanın hız kesmeden yaygınlaşması, aşırı iklim olayları, yeryüzü canlılığının çok kısa sürede kitlesel yok oluşu (plastiğe boğulan okyanuslar, nesilleri tükenen hayvanlar ve bitkiler), peş peşe yaşanan pandemiler, giderek daha fazla hissedilmeye başlayan kuraklık ve muhtemel susuzluk, her şeyi bilen ve hiçbir kılavuza ihtiyaç duymayan fail özne olarak insanın sorgulanmasını da beraberinde getirdi. Bir anlamda bu, Aydınlanma projesinin en önemli yanlarından birisinin, 'tekno-bilimsel alandaki ilerleme ile bireysel özgürleşme, yani insan özgürlügündeki ilerleme arasındaki bağlaşıma dair sarsılmaz kabulün’ (Iftode 2020: 6-7) sorgulanmasıydı. İnsanın hem karşılaştığı soru ve sorunların analizini hem de bunlara verilebilecek yanıtları ve tepkileri aklıyla ve iradesiyle hayata geçirebilecek kudrette olduğuna gerek doğal gerek sosyo-politik yaşamda kontrolü ve olayların gidişatına hakimiyeti elinde bulunduran bir varlık, kurucu fail oluşuna bu nedenlerle evrenin merkezi olduğuna, yüceliğine dair kabullere tutunmak giderek zorlaşmaya başladı.

Bütün bunlar neticesinde hümanizm temel değerleri, ilkeleri ve varsayımlarıyla mercek altına sokulurken siyasal düşüncenin pek çok tartışma konusunda yaşanan moment burada da kaçınılmaz olarak gelmişti: İkili karşıtlıkların sorgulanması. Bu kez soru şuydu: Hümanizmin tek alternatifi anti-hümanizm midir? Hümanizmi etik, politik, epistemolojik çeşitli saiklerle eleştirmek ve sorgulamak, itirazlar dile getirmek onun 
bütün değerlerini de göz ardı etmek ya da reddetmek anlamına gelmek zorunda mıdır? Hümanizme antihümanizmle cevap vermek aslında aynı kalıbı tekrarlamak anlamına gelmiş olmuyor muydu? Yani evrenselci-tekçi olmakla itham edilen bir anlayışa farklı geleneklerden, farklı kuramsal akımlardan, farklı önceliklerle yöneltilen çoğul eleştirilerin tek bir teorik pozisyonda toplanıp eritilmeye çalışılması doğru muydu? Ve hatta bu mümkün müydü?

Posthümanizm insanlığın sonundan değil, daha ziyade, "belirli bir tür insanlığın" sonunun gelmesinden bahsetmektedir: $\mathrm{Bu}$, failliği ve seçimleriyle iradesini gerçekleştiren, kendini tekil ve özerk varlıkların toplamı olarak kavramlaştırmış insan modelidir (Hayles’ten aktaran Hamzeçebi ve Şen 2019). Posthümanizm, insanın yüceltilmesinin karşısına 'insanın kendine yakıştırdığ1 ve hümanist düşünceyle yaygınlık kazanan üstünlük söylemini eleştiriye tâbi tutarak dolaşıklığa dayalı varoluşumuzu algılanabilir kılma ve bir arada yaşamı mümkün kılacak ilişkilenme ve dayanışma biçimlerini düşünme’ davetiyle çıkar. (Hamzeçebi ve Şen 2019). Bu anlamda posthümanizm 'hümanizm ile antihümanizm arasındaki zıtlaşmanın sona erişini simgeler' (Braidoti'den aktaran Kumm v.d.: 343). İnsan, tümüyle özerk değil uçsuz bucaksız ilişkilerin içinde konumlanmış olarak ele alınır; cinsiyetçilik, 1rkçılık, türcülük (insan türünün bazı avantajları ve ayrıcalıkları olduğu düşüncesi) gibi kısıtlayıcı ve ayrımcı anlayışlar terk edilir; var oluşun girift, sembiyotik, hibrid, karışık ve akışkan olduğu kabul edilir; hiçbir şey tümüyle özerk ve bağımsız değildir (Bejan 2020: 39)

Özetle, posthümanizm hümanizmi özü itibariyle insanın özgürleşme arayışıyla bağlantılandıran, bu bakımdan önemli bulan ancak özgürleşimin çoğul okumalarının/kavramsallaştırmalarının olduğunu kabul ederek bu nedenle insani özgürleşimin önündeki engellerin de çok çeşitli, çok boyutlu, çok katmanlı olduğu gerçeğiyle yüzleşen, o nedenle hümanizmi ve onun eleştirilerini farklı özgürlük ve özgürleşme anlayışlarına ve mücadelelerine açılım sağlaması bakımından ele almayı benimseyen bir yaklaşımdır. 


\section{Sonuç}

Bitirirken, yazıyı kendisinden alıntılarla kurguladığımız Diogenes’e geri dönebiliriz. Onun insan olabilmek için koyduğu koşul şöyledir: İçinde bulunduğu toplumun doğrularını sorgulayarak o ön kabullerden kendini kurtaran insan özgürdür ve o gerçek insandır. Bunu yapabilmek ise hem Sokrates'in hem Platon'un dikkat çektiği üzere, insanın algılayabildiği dünyanın koyduğu sınırlardan kendisini özgürleştirmesiyle mümkündür. Yukarıda gördüğümüz üzere, bu bakış açısı bambaşka bir insan tanımına ve buna bağlı olarak başka bir özgürlük anlayışına, insanın ancak kendisinin algılayamayacağı bazı aşkın güçlere teslim olursa özgür olacağı şeklinde bir özgürlük anlayışına yolu açmıştır. Buradan geri dönüş ise insanın mutlaka ve sadece kendi duyu organlarıyla edindiği tecrübelere ve kendi akıl ve muhakemesine güvenmesi ve onu aş(tığına inanıl)an otoritelerden kendini özgürleştirmesi gerektiği şeklindeki anlayışın hâkim olmasıyla gerçekleşmiştir. İnsanın tek otorite olarak salt kendi akı1 ve iradesini görmesinden, her şeyi anlayıp bilebilecek ve eyleyebilecek bir fail olarak kendisini görmesinden kaynaklanan diğer varlıklar karşısında üstünlük duygusu ve bazılarının dediği şekliyle aşırı özgüven. Gördüğümüz üzere, posthümanizm tartışmalarının en büyük (potansiyel) katkısı, çok uzun süredir salınmakta olan bu sarkaca hafifçe dokunarak onu sakinleştirmiş olması, insanın 'gerçekte' ne olduğuna dair düşünüşü ikili karşıtlıkların sınırlayıcılığından çıkarmayı deniyor olmasıdır. İnsanın gerçek gücü belki de kendisini neyin kısıtladığını fark edebilmek konusundaki gücüdür, bu eğer bir nevi kibirse bunu aşarak özgürleşmek de insanın da gücüne içkin olarak düşünülebilir. Ayrıca insan, her zaman farklı meydan okumalarla karşılaşacağını ve bunlarla başa çıkarken farklı özgürleşim mücadeleleri yürütmek zorunda kalacağını, bunu yaparken de kendisini sürekli olarak yeniden ve yeniden inşa edeceğini, kendisini her seferinde yeniden tanımlamak zorunda kalacağını kabul etmek zorundadır. İnsan ne evrendeki her şeyin tek ölçüsüdür ne de kendi dünyasının dişında/üstünde/ötesinde yer alan güçler karşısında haddini bilmekle yükümlü bir varlıktır. İnsan olmak hem haddini bilmekle hem de haddini aşabilmeyi bilmekle tanımlanacak bir niteliktir. Çok uzun zamandır bir o tarafa bir bu tarafa salınım halince olan sarkaç belki de sonunda ortada bir yerde 
durmak üzeredir. Böyle bakıldığında, posthümanizm, aslında insanın ne olduğuna dair tartışmaların ve düşüncelerin ilk örneklerinden çok da uzağa düşmemektedir. Posthümanizm de netice itibariyle insanı hem kısıtlılı̆̆ını/sınırlarını hem de potansiyelini fark etmeye davet etmektedir. Posthümanizmin ayırt edici özelliği bu sorgulamaları insanmerkezcilikten uzakta kalarak yapabilmek gerektiğini savunmasında; insanın kendisini salt yaratan, kuran, inşa eden değil aynı zamanda yarattıkları ve kurdukları tarafından da kurulan bir varlık olduğunu fark ederek yap(tır)mak istemesindedir. Ancak bu potansiyelin hakkını tam manasıyla verebilmek onu daha önceki arayışlarla birlikte ele alarak, böyle bir sorgulama ihtiyacının nereden doğduğuna dair bir farkındalık geliştirerek mümkün olabilir. 


\section{KAYNAKÇA}

ADORNO, Thedor W., Max HORKHEIMER (2002). Dialectic of Enlightenment, Stanford: Stanford University Press.

ARENDT, Hannah (2008). İnsanlık Durumu, İstanbul: İletişim Yayınları.

BEJAN, Petru (2020). "Crises and Resolutions of Humanisms. From the Vitruvian Man to the Augmented Man," Hermeneia, 24/2020: 29-48.

ÇEVİK, Cengiz (Der.) (2020) Antisthenes Diogenes Kinik Felsefe Fragmanları, İstanbul: İş Bankası Kültür Yayınları.

FOUCAULT, Michel Kelimeler ve Şeyler İnsan Bilimlerinin Bir Arkeolojisi, 2. Baskı, çev. Mehmet Ali Kılıçbay, İstanbul: İmge.

FROMM, Eric (2020) Insan Olmak Üzerine, Modern Dünyada Yabancllaşmaya Dair Hümanist Bir Bakış, 3. Baskı, çev. Şükrü Alpagut, İstanbul: Say Yayınları.

FUKUYAMA, Franscis (2002). Our Posthuman Future, Consequences of the Biotechnology Revolution, New York: Farrar, Strauss \& Giroux.

GLAZIER, W. Jacob (2018). "Tricking Posthumanism: From Deleuze to (Lacan) to Haraway" Critical Horizons 19(2)/2002: 173-185.

HAMZEÇEBİ Ezgi, Merve ŞEN (2019). "Varlık'a bir yanıt: Posthümanizm ve gözden kaçan imkânlar," Erişim tarihi 30 Kasım 2020, (https://t24.com.tr/k24/yazi/varlik-a-bir-yanit-posthumanizm-ve-gozden-kacanimkanlar,2140).

HAYLES, Katherine (1999). How We Became Posthuman, Chicago: The University of Chicago Press.

IFTODE, Cristian (2020). "The Dispute between Humanism and Anti-humanism in the 20th Century: Towards an Archeology of Posthumanism," Hermeneia, 24/2020: 5-14.

KUMM Brian E., BERBARY Lisbeth A., and Bryan S. R. GRIMWOOD (2019). "For Those to Come: An Introduction to Why Posthumanism Matters," Leisure Sciences, 41(5)/2019: 341-347.

NEWMAN, Saul (2001). Bakunin'den Lacan'a Anti-Otoriteryanizm ve İktidartn Altüst Oluşu, İstanbul: Ayrıntı Yayınları.

O'MAHONEY Paul (2020). "Nietzsche's Posthuman Political Vision", The European Legacy, 25(1)/2019: 1-19.

PLATON (2006). Devlet, çev. Sabahattin Eyüboğlu ve M. Ali Cimcoz, İstanbul: İş Bankası Kültür Yayınları. 
Funda GENÇOĞLU, “Posthumanizm Tartışmasının Düşündürdükleri: Haddini Bilmek ile Haddini Aşmak Arasında İnsan," Kaygı, 20(I)/2021: 70-91.

SENECA (2019). Hoşgörü Üzerine \& Ruh Dinginliği Üzerine, Ankara: Doğu Batı Yayınları.

WOLLSTONECRAFT, Marry (2007). Kadın Haklarının Gerekçelendirilmesi, çev. Deniz Hakyemez, İstanbul: İş Bankası Kültür Yayınları. 